\title{
Lactation Performance of Mid-Lactation Dairy Cows Fed Ruminally Degradable Protein at Concentrations Lower Than National Research Council Recommendations ${ }^{1}$
}

\author{
J. Cyriac, ${ }^{*}$ A. G. Rius, ${ }^{\star}$ M. L. McGilliard, ${ }^{*}$ R. E. Pearson, ${ }^{*}$ B. J. Bequette,, and M. D. Hanigan ${ }^{\star 2}$ \\ *Department of Dairy Science, Virginia Polytechnic Institute and State University, Blacksburg 24061 \\ †Department of Animal and Avian Sciences, University of Maryland, College Park 20742
}

\begin{abstract}
The aim of this study was to test whether feeding of diets containing lower proportions of ruminally degradable protein (RDP) but with a constant proportion of ruminally undegradable protein (RUP) alters feed intake, milk production and yield, and the apparent efficiency of $\mathrm{N}$ utilization by mid-lactation dairy cows. During the covariate period (d 1 to 28), 40 mid-lactation cows (36 Holstein and 4 Jersey $\times$ Holstein cross-breds) were fed a common diet formulated to contain $11.3 \%$ of diet dry matter (DM) as RDP. During the treatment period (d 29 to 47 ), cows were randomly assigned to 1 of 4 diets formulated to contain $11.3,10.1,8.8$, or $7.6 \%$ RDP, whereas ruminally undegradable protein remained constant at $7.1 \%$ of DM. All diets contained $47.5 \%$ forage and $52.5 \%$ concentrate on a DM basis. Dry matter intake was significantly reduced for the 7.6\% RDP diet. The lowest RDP content was associated with a trend for reduced milk yield. Dietary RDP had no effect on body weight or milk fat, protein, and lactose contents. Milk protein yield was not affected by RDP level; however, milk fat yield decreased linearly as dietary RDP was reduced. Concentrations of plasma essential amino acids were unaffected, whereas milk urea-N concentrations decreased linearly as dietary RDP content was reduced. The apparent efficiency of $\mathrm{N}$ utilization for milk $\mathrm{N}$ production increased from $27.7 \%$ on the $11.3 \%$ RDP diet to $38.6 \%$ on the $7.6 \%$ RDP diet. The dietary RDP requirement of cows in this study was apparently met between 15.9 and $14.7 \%$ dietary crude protein. Milk production was not significantly affected by the $8.8 \%$ RDP ( $15.9 \%$ crude protein) diet even though the NRC (2001) model predicted that RDP supply was $87 \%$ of that required, suggesting the current
\end{abstract}

\footnotetext{
Received February 21, 2008.

Accepted July 22, 2008.

${ }^{1}$ Mention of any trademark or proprietary product in this paper does not constitute a guarantee or warranty of the product by the USDA or ARS and does not imply its approval to the exclusion of other products that also may be suitable.

${ }^{2}$ Corresponding author: mhanigan@vt.edu
}

NRC recommendations for RDP may be overestimated for mid-lactation dairy cows in this study.

Key words: ruminally degradable protein, protein requirement, milk production, dairy cow

\section{INTRODUCTION}

Poor conversion efficiency of dietary $\mathrm{N}$ to milk or tissue $\mathrm{N}$ gain by ruminants (Bequette et al., 2003) leads to significant losses of $\mathrm{N}$ via feces and urine. Urinary $\mathrm{N}$ is rapidly converted to ammonia during manure collection and storage as compared with fecal N (Varel et al., 1999). Volatilized ammonia reduces air quality by catalyzing small particle formation (James et al., 1999). The ability to reduce dietary protein levels yet maintain milk production and performance has the potential to reduce $\mathrm{N}$ release to the environment by ruminants and may have economic advantages for the producer by reducing feed costs (Tamminga, 1992).

Lactating dairy cows in the United States are generally fed to requirements as set by NRC (2001). These recommendations reflect our current nutritional knowledge. Protein requirements of a lactating dairy cow are met from the supply of AA reaching the small intestines in microbial and undegraded feed protein. The degradation of dietary feed $\mathrm{CP}$ in the rumen is important because it supports microbial growth in the rumen. On average $59 \%$ of the NAN that reaches the duodenum is supplied by microbial CP, and the remainder is RUP and endogenous protein secretions (Clark et al., 1992).

Some evidence suggests that ruminants can remain productive at much lower $\mathrm{N}$ inputs than are currently recommended and used in practice (Christensen et al., 1993, 1994). Insufficient RDP could lead to a ruminal $\mathrm{NH}_{3}$ deficiency that would depress microbial growth. However, this does not always lead to a reduction in MP availability to the animal because reductions in microbial $\mathrm{N}$ flow can be offset by increases in RUP flow (Santos et al., 1998). However, an RDP deficiency can also precipitate depressed fiber digestion, which can lead to reduced DMI and energy supply to the animal (Firkins et al., 1986; Allen, 2000). 
Thus, it is critical to provide enough RDP to meet the requirements of ruminal microbes. The NRC (2001) RDP requirements for dairy cows generally range from 9.5 to $10.5 \%$ of dietary DM depending on diet, animal characteristics, and production level. Recommendations for RDP and RUP in the NRC (2001) were based on a regression approach using literature data. Although the resulting regression equation had an $\mathrm{r}^{2}$ of 0.52 , few of the experiments used in the evaluation utilized RDP levels that were well below the current recommendation. Thus, it is possible the current requirements are set too high because of inadequate range in the data used to derive them. Results from research trials where the RDP:RUP ratio was changed while holding CP constant are difficult to interpret because the decreasing concentration of RDP is confounded with the increasing concentration of RUP. Gressley and Armentano (2007) recently observed no changes in milk production when 10.1 and $7.4 \%$ RDP diets were compared. Thus, it would appear that RDP requirements may be greater than necessary under some conditions. Establishment of accurate requirement equations is imperative because overfeeding protein causes decreased animal efficiency and increased $\mathrm{N}$ excretion (Kalscheur et al., 2006).

The objectives of this work were to determine the effects of reduced dietary RDP with constant RUP [according to NRC (2001) predictions] on intake, milk production and composition, plasma AA concentrations, and apparent N efficiency and to test the NRC (2001) model for accuracy in predicting RDP requirements in mid-lactation dairy cows.

\section{MATERIALS AND METHODS}

\section{Animals and Diets}

All animal procedures were approved by the Virginia Tech Animal Care and Use Committee. Thirtysix Holstein (29 multiparous and 7 primiparous) and 4 primiparous Jersey $\times$ Holstein cross-bred cows $(147 \pm$ 38 DIM, $594 \mathrm{~kg}$ of BW) were used. Cows selected had an average 305-d ME milk yield of 13,209 $\pm 1,500 \mathrm{~kg}$. Cows were arranged into 4 groups to equalize DIM, parity, BW, milk production, and pregnancy status and then randomly assigned to receive 1 of 4 diets that varied in the proportion of RDP in the diet DM. Cows were housed in a free-stall unit at the Virginia Tech Dairy Science complex, fed once daily using Calan Broadbent individual animal feeders (American Calan Inc., Northwood, $\mathrm{NH}$ ), and milked twice daily at 0130 and $1400 \mathrm{~h}$. One cow was removed from the study for health-related issues.

Diets were formulated to meet NRC (2001) recommendations for $\mathrm{NE}_{\mathrm{L}}$, RUP, minerals, and vitamins for a mid-lactation dairy cow weighing $612 \mathrm{~kg}$ and producing $36.3 \mathrm{~kg}$ of milk per day containing $3.5 \%$ fat. Final diets contained $47.5 \%$ forage and $52.5 \%$ concentrate on a DM basis (Table 1). Two concentrate mixes (A and D) were formulated to contain high and low RDP and $\mathrm{CP}$ contents and a constant RUP content. Concentrate mixes were blended with the forages to attain 4 diets containing $11.3(\operatorname{diet} A), 10.1(\operatorname{diet} B), 8.8(\operatorname{diet} C)$, or $7.6 \%$ (diet D) RDP on a DM basis and an RUP content of $7.1 \%$ of diet DM. Diets were fed as total mixed rations in amounts to ensure 10\% daily refusals. Initially, cows were fed diet A during a covariate period (d 1 to 28). During the subsequent treatment period (d 29 to 47), cows were fed their respective experimental diet. Cows were transitioned to the experimental diets over a 4 -d period.

\section{Sample Collection and Analysis}

Feed intake and refusals were recorded daily. Milk weights were recorded at each milking and BW were recorded twice daily as the cows exited the milking parlor. Milk samples were taken on $3 \mathrm{~d}$ for each milking during the last week of the covariate and treatment periods. Blood samples were collected from the coccygeal vessels into sodium heparin tubes immediately after the afternoon milking on $2 \mathrm{~d}$ during the last week of each period, placed on ice, transported to the laboratory, and the blood cells removed by centrifugation. Plasma samples were stored at $-20^{\circ} \mathrm{C}$ until analyses. Two individuals measured the BCS at the end of each period.

Milk samples were submitted to United Federation of DHIA (Blacksburg, VA) for determination of milk true protein, fat, lactose and SCC using a Fossomatic 4000 Combi infrared analyzer (Eden Prairie, MN). Concentrations of MUN were determined using a modification of the Berthelot procedure (ChemSpec 150 Analyzer; Bentley Instruments, Chaska, MN). Urine N, fecal N, and $\mathrm{N}$ efficiency were predicted using the following equations (Wattiaux and Karg, 2004):

$$
\begin{aligned}
& \text { Urine } \mathrm{N} \text { output }(\mathrm{g} / \mathrm{d})=0.0283 \times \mathrm{MUN}(\mathrm{mg} / \mathrm{dL}) \\
& \times \mathrm{BW}(\mathrm{kg}) \text {; } \\
& \text { Fecal } \mathrm{N}(\mathrm{g} / \mathrm{d}) \text { = intake } \mathrm{N}(\mathrm{g} / \mathrm{d}) \text { - urinary } \mathrm{N} \text { output } \\
& \text { (g/d) - milk N (g/d); and } \\
& \mathrm{N} \text { efficiency }(\%)=\text { milk } \mathrm{N}(\mathrm{g} / \mathrm{d}) / \text { intake } \mathrm{N}(\mathrm{g} / \mathrm{d}) \\
& \times 100 \text {. }
\end{aligned}
$$

The DM percentages of corn silage and haylage were determined weekly, and diets were adjusted accordingly to ensure a constant forage-to-concentrate ratio 
Table 1. Formulated composition of experimental diets

\begin{tabular}{|c|c|c|c|c|}
\hline \multirow[b]{2}{*}{ Item } & \multicolumn{4}{|c|}{$\mathrm{RDP}, \%$ of diet $\mathrm{DM}^{1}$} \\
\hline & 11.3 & 10.1 & 8.8 & 7.6 \\
\hline \multicolumn{5}{|l|}{ Ingredient ( $\%$ of $\mathrm{DM})$} \\
\hline Corn silage & 39.7 & 39.7 & 39.7 & 39.7 \\
\hline Mix grass + legume silage & 7.8 & 7.8 & 7.8 & 7.8 \\
\hline Whole linted cotton seed & 2.9 & 2.9 & 2.9 & 2.9 \\
\hline Rolled high moisture corn grain & 15.5 & 15.5 & 15.5 & 15.5 \\
\hline Soybean hulls & 9.7 & 11.4 & 13.0 & 14.7 \\
\hline Soybean meal, solvent-extracted & 20.4 & 13.6 & 6.8 & 0.0 \\
\hline Protected soybean meal ${ }^{2}$ & 0.0 & 4.1 & 8.3 & 12.4 \\
\hline Ground dry corn grain & 0.6 & 1.3 & 2.0 & 2.7 \\
\hline Tallow & 0.9 & 1.2 & 1.5 & 1.8 \\
\hline Limestone & 1.8 & 1.7 & 1.7 & 1.6 \\
\hline Dicalcium phosphate $^{3}$ & 0.0 & 0.1 & 0.2 & 0.3 \\
\hline Sodium bicarbonate & 0.2 & 0.2 & 0.2 & 0.2 \\
\hline Salt & 0.5 & 0.5 & 0.5 & 0.5 \\
\hline Trace mineral and vitamin $\operatorname{mix}^{4}$ & 0.1 & 0.1 & 0.1 & 0.1 \\
\hline \multicolumn{5}{|l|}{ NRC estimate $^{5}$} \\
\hline RDP, $\%$ of DM & 11.3 & 10.1 & 8.8 & 7.6 \\
\hline RUP, $\%$ of DM & 7.1 & 7.1 & 7.1 & 7.1 \\
\hline NFC, $\%$ of DM & 41.9 & 41.9 & 41.8 & 41.8 \\
\hline NDF, \% of DM & 30.0 & 30.8 & 31.7 & 32.5 \\
\hline $\mathrm{ADF}, \%$ of $\mathrm{DM}$ & 20.3 & 20.9 & 21.5 & 22.1 \\
\hline Crude fat, $\%$ of DM & 4.1 & 4.6 & 5.0 & 5.5 \\
\hline $\mathrm{NE}_{\mathrm{L}} \mathrm{Mcal} / \mathrm{kg}$ & 1.6 & 1.6 & 1.6 & 1.6 \\
\hline RDP supplied, $\mathrm{g} / \mathrm{d}$ & 2,611 & 2,328 & 2,045 & 1,762 \\
\hline $\mathrm{RDP}$ required, $\mathrm{g} / \mathrm{d}$ & 2,311 & 2,319 & 2,328 & 2,336 \\
\hline RDP balance, g/d & 301 & 9 & -282 & -574 \\
\hline RUP supplied, g/d & 1,646 & 1,648 & 1,649 & 1,651 \\
\hline RUP required, $\mathrm{g} / \mathrm{d}$ & 1,239 & 1,374 & 1,510 & 1,645 \\
\hline RUP balance, $\mathrm{g} / \mathrm{d}$ & 407 & 273 & 140 & 6 \\
\hline MP supplied ${ }^{6} \mathrm{~g} / \mathrm{d}$ & 2,793 & 2,690 & 2,586 & 2,483 \\
\hline MP allowable milk, $\mathrm{kg} / \mathrm{d}$ & 44.2 & 41.6 & 39 & 36.4 \\
\hline
\end{tabular}

${ }^{1} \mathrm{RDP}$ (DM basis) according to NRC, 2001.

${ }^{2}$ Hivap, Land O' Lakes/Purina Feed, Statesville, NC.

${ }^{3}$ Contained $22 \% \mathrm{Ca}$ and $19.3 \% \mathrm{P}$.

${ }^{4}$ Land O' Lakes/Purina Feed, Statesville, NC; formulated to provide (per kg of dietary DM) $25 \times 10^{5}$ IU of vitamin $\mathrm{A}, 400,000 \mathrm{IU}$ of vitamin $\mathrm{D}$, and $10 \times 10^{5} \mathrm{IU}$ of vitamin $\mathrm{E}, 0.1 \mathrm{mg}$ of $\mathrm{Co}, 12 \mathrm{mg}$ of $\mathrm{Cu}, 0.7 \mathrm{mg}$ of I, 60 $\mathrm{mg}$ of Fe, $48 \mathrm{mg}$ of $\mathrm{Mn}, 48 \mathrm{mg}$ of $\mathrm{Zn}, 0.3 \mathrm{mg}$ of Se.

${ }^{5}$ Calculated using the NRC model (2001) and observed input values.

${ }^{6}$ Assumes microbial yields are compromised by an RDP deficiency.

(47.5:52.5) on a DM basis. The TMR, orts, and major ingredients of the TMR (corn silage, high moisture rolled corn, mixed grass legume silage, cotton seed, and the grain mix) were sampled each day during the last week of each period, composited for the week, and stored at $-20^{\circ} \mathrm{C}$ until analyses. Frozen composited samples were later thawed, oven-dried at $60^{\circ} \mathrm{C}$ to determine DM, ground through a Wiley mill (1-mm screen; Arthur H. Thomas, Philadelphia, PA), and submitted for nutrient analyses (Dairyland Laboratories, Arcadia, WI). Kjeldahl N, ether extract, ash, and DM contents were determined according to AOAC methods (AOAC, 1997). Acid detergent fiber and lignin were determined according to AOAC (1997; method 973.18) and NDF according to Van Soest et al. (1991). Soluble CP was analyzed as described by Licitra et al. (1996). Starch was measured as dextrose after treating samples with glucoamylase using a YSI 2700 Select Biochemistry
Analyzer (application note \#319, Yellow Springs, OH) and ether extract by AOAC (1997). Minerals were quantified according to AOAC methods (1997; method 985.01) using an inductively coupled plasma spectrometer (Thermo Jarrell Ash, Franklin, MA). Packed cell volume (\%) was determined by centrifuging heparinized blood in a microhematocrit tube at $15,000 \times g$ for $5 \mathrm{~min}$. Fresh blood was centrifuged $(2,000 \times g$ for 20 min at $4^{\circ} \mathrm{C}$ ) to separate plasma, and AA concentrations were determined by isotope dilution techniques using a gas chromatograph coupled to a mass spectrometer as described previously (El-Kadi et al., 2006).

\section{In Situ Study}

To determine ruminal degradability characteristics of $\mathrm{CP}$ for each major feed ingredient used in the study, one ruminally cannulated, dry, nonpregnant cow was used. 
The cow was housed in an individual pen equipped with feeders and clean water. The cow was fed a lactating cow TMR containing 18\% CP once daily for ad libitum intake. An in situ analysis of the individual feed ingredients [corn silage, high moisture rolled corn, mixed grass legume silage, concentrate mix A and D, soybean meal (SBM), soybean hulls, and protected SBM (HiVap, Land O' Lakes/Purina Feed, Statesville, $\mathrm{NC}$ ] was performed on d 8 for $24 \mathrm{~h}$. Samples for the analyses were dried at $60^{\circ} \mathrm{C}$ and ground to $2 \mathrm{~mm}$. Approximately $4.5 \mathrm{~g}$ of the sample were placed in $10 \times 20$ cm polyester bags (Ankom Technology, Macedon, NY) with a pore size of $50 \mu \mathrm{m}( \pm 15)$ and suspended in the rumen in a large $(36 \times 42 \mathrm{~cm})$ nylon mesh bag.

Samples were placed in the rumen in reverse order and removed simultaneously at the end of the experiment. The bags resided in the rumen for $2,4,8,12$, and $24 \mathrm{~h}$. A 0 -h sample was immersed in $39^{\circ} \mathrm{C}$ water for $20 \mathrm{~min}$. No SBM sample was available in the bag after 24-h incubation for further analysis. After incubation all other bags were rinsed in cold water, washed in a Sears Kenmore washing machine using the knit, cold wash cycle, and dried at $60^{\circ} \mathrm{C}$ for $48 \mathrm{~h}$. Residues were ground to $1 \mathrm{~mm}$ and analyzed for $\mathrm{CP}$ content. Crude protein disappearance was calculated as the difference between the original CP mass and the mass remaining after ruminal fermentation. Digestion rates were calculated by using the Proc NLin procedure of SAS.

Protein degradation rates were estimated according to NRC (2001):

$$
\text { Undegraded protein }(\%)=\mathrm{B} \times \mathrm{e}^{(-\mathrm{kd} \times \mathrm{t})} \text {, }
$$

where $B$ represented the amount insoluble at $0 \mathrm{~h},(\%)$, $k d$ represented the degradation rate of $B(\% / \mathrm{h})$, and $t$ represented time in the rumen $(\mathrm{h})$.

\section{NRC Model Analysis}

The NRC (2001) model was evaluated using treatment means. Observed milk yields, milk composition, and BW were used as inputs. Diet composition was set to values in Table 1 and ingredient composition to observed values. Observed DMI were used to set the feeding rate of each ingredient. The observed $\mathrm{CP}$ contents of SBM, soyhulls, ground dry corn, and protected SBM were used to calculate the total $\mathrm{CP}$ contents of concentrate mixes $\mathrm{A}$ and $\mathrm{D}$. These calculated values were compared with the observed CP values of the concentrate mixes and found to deviate slightly. Because the SBM and protected SBM were the major ingredients that contributed to the $\mathrm{CP}$ contents of concentrate mixes $\mathrm{A}$ and $\mathrm{D}$, the $\mathrm{CP}$ values for these 2 ingredients were adjusted to achieve calculated $\mathrm{CP}$ contents for the grain mixes that were equal to the observed. These adjusted $\mathrm{CP}$ values and the observed $\mathrm{NDF}$ and $\mathrm{DM}$ values for SBM and protected SBM were used with the observed CP, NDF, and DM for other major forage and grain mix ingredients as inputs to the NRC (2001) model to generate predicted RDP, RUP, MP, and energy supplies and animal requirements.

\section{Statistical Analysis}

Daily DMI and milk yield in the last week of each period were analyzed statistically. Means of milk composition $(\mathrm{n}=6)$ and blood plasma amino acids $(\mathrm{n}=$ 2) were calculated for the last week of each period for each cow. Statistical analyses were done using PROC MIXED of SAS (2001) with a model that included pretreatment values as a covariate:

$$
\mathrm{Y}_{\mathrm{ijkl}}=\alpha+\mathrm{T}_{\mathrm{i}}+\mathrm{P}_{\mathrm{j}}+\beta \mathrm{X}_{(\mathrm{ij}) \mathrm{k}}+\mathrm{TP}_{\mathrm{ij}}+\mathrm{C}_{(\mathrm{ij}) \mathrm{k}}+\mathrm{e}_{\mathrm{ijk} \mathrm{kl}},
$$

where $Y_{\mathrm{ijkl}}=$ lth observation of kth cow of jth parity in ith treatment, $\alpha=$ intercept, $T_{i}=$ fixed effect of the ith treatment ( $\mathrm{i}=1$ to 4 ), $\mathrm{P}$ = fixed effect of the jth parity ( $\mathrm{j}=1$ to 4 ), $\beta=$ covariate effect of period $1, \mathrm{TP}_{\mathrm{ij}}=$ the fixed interaction between the ith treatment and jth parity, $\mathrm{C}_{(\mathrm{ij}) \mathrm{k}}=$ random effect of the kth cow nested within the ith treatment and jth parity, $(\mathrm{k}=1$ to 4$)$, and $\mathrm{e}_{\mathrm{ijkl}}$ $=$ residual error. Unless otherwise stated, significance was declared at $P<0.05$. All results were reported as least squares means.

\section{RESULTS AND DISCUSSION}

The observed chemical composition of experimental diets is presented in Table 2. The dietary dry matter content varied from 48.0 to $49.6 \%$ among diets. Measured CP contents of diets A, B, C, and D were 18.4, $16.8,15.2$, and $13.6 \%$ of diet DM, respectively. Chemical composition of individual feed ingredients is reported in Table 3. Concentrate mix D was significantly lower in $\mathrm{CP}$ than the formulated value which was due to lower than expected CP in the protected SBM ( $51.6 \%$ vs. the expected value of $53 \%$ ). Results of the in situ analyses for $\mathrm{CP}$ are presented in Table 4 . The soluble fraction of $\mathrm{CP}$ (fraction A) were generally greater than NRC reported values. However, observed degradation rates of major protein sources in the diet were similar to NRC reported values. The degradation rate for SBM was found to be $6.0 \% / \mathrm{h} \pm 1 \%$. The NRC reports a value of $7.5 \% / \mathrm{h}$, which given the SE of our estimate, would not be significantly different. Soyhulls had an observed rate of $6 \% / \mathrm{h}$, whereas the NRC lists a rate of $6.2 \% / \mathrm{h}$. 
Table 2. Observed chemical composition of experimental diets

\begin{tabular}{lrrrr}
\hline & \multicolumn{4}{c}{ RDP, \% of diet DM } \\
\cline { 2 - 4 } Item $^{1}$ & 11.3 & 10.1 & 8.8 & 7.6 \\
\hline DM, \% of diet & 49.6 & 49.1 & 48.0 & 48.1 \\
CP, \% of DM & 18.4 & 16.8 & 15.2 & 13.6 \\
Soluble protein, \% of CP & 41.9 & 41.4 & 40.9 & 40.4 \\
ND-ICP, \% of CP & 11.3 & 12.6 & 14.0 & 15.8 \\
AD-ICP, \% of CP & 4.5 & 4.8 & 5.1 & 5.6 \\
OM, \% of DM & 92.7 & 92.8 & 92.9 & 93.0 \\
NDF, \% of DM & 31.4 & 32.8 & 34.1 & 35.4 \\
ADF, \% of DM & 18.6 & 20.0 & 21.4 & 22.8 \\
Lignin, \% of DM & 3.2 & 3.3 & 3.4 & 3.5 \\
\hline
\end{tabular}

${ }^{1} \mathrm{ND}-\mathrm{ICP}=$ neutral detergent insoluble $\mathrm{CP} ; \mathrm{AD}-\mathrm{ICP}=$ acid detergent insoluble $\mathrm{CP}$.

We observed a rate of $5.0 \% / \mathrm{h}$ for rolled, high-moisture corn, whereas the NRC lists a rate of $5.1 \% / \mathrm{h}$.

Predicted and observed ruminal CP degradation from concentrate mix A, concentrate mix D, SBM, and protected SBM are presented in Figure 1. The rate of disappearance of concentrate mix A and SBM were greater than that of concentrate mix D and protected SBM as expected. The 24-h degradabilities of the concentrate mixes were $40 \%$ units apart as would be expected given the differences in degradation rates of the SBM and protected SBM, the major contributors of $\mathrm{CP}$ to the grain mixes.

Least squares means for DMI, milk yield and composition, and BW of cows fed experimental diets are given in Table 5. Pair-wise least squares means comparisons (Tukey) indicated that DMI of cows fed the low RDP $(7.6 \%)$ diet were significantly less $(P<0.0001)$ than that of cows receiving the other diets, but no differences among the other diets were observed. No treatment effects were observed for BW and body condition scores. Inadequate RDP can lead to reduced ruminal ammonia concentrations, which causes a depression in fiber degradation (Firkins et al., 1986) and reduces DMI (Allen, 2000). Our results indicated that 7.6\% RDP diets may not have met the $\mathrm{N}$ requirement of rumen microbes, leading to decreased DMI. However, diets with $8.8 \%$ RDP or greater appeared to be sufficient; no significant differences in DMI were observed $(P=0.24)$. Our observations contrast with the results of Gressley and Armentano (2007) who reported no change in DMI when a $7.4 \%$ RDP diet was fed as compared with a $10.4 \%$ RDP diet. Similarly, Kalscheur et al. (2006) and Reynal and Broderick (2005) did not observe changes in DMI when RDP concentrations as low as $6.8 \%$ were fed. These studies and the results from the $8.8 \% \mathrm{RDP}$ diet herein indicate that ruminal $\mathrm{NH}_{3}$ concentrations are apparently adequate for maintenance of DMI at RDP concentrations less than that recommended by the NRC (2001).

Milk production was not significantly affected by treatment (Table 5). However, there was a trend for a loss in production associated with the $7.6 \% \mathrm{RDP}$ or $14.7 \% \mathrm{CP}$ diet $(P=0.09)$. The reduced DMI for this particular diet would likely be associated with a reduction in energy supply to the animal and thus the numerical reduction in milk yield. Milk yield associated with the $8.8 \% \mathrm{RDP}$ or $15.9 \% \mathrm{CP}$ diet was not significantly less than yields associated with the higher RDP diets.

Table 3. Observed chemical composition of individual ingredients in the experimental diet

\begin{tabular}{|c|c|c|c|c|c|c|c|c|c|}
\hline Item $^{1}$ & $\begin{array}{c}\text { Concentrate } \\
\operatorname{mix} \mathrm{A}\end{array}$ & $\begin{array}{c}\text { Concentrate } \\
\operatorname{mix} \text { D }\end{array}$ & $\begin{array}{l}\text { Corn } \\
\text { silage }\end{array}$ & Haylage & $\begin{array}{c}\text { Cotton } \\
\text { seed }\end{array}$ & $\mathrm{HMC}^{2}$ & SBM & $\mathrm{SH}$ & $\begin{array}{l}\text { Protected } \\
\mathrm{SBM}^{3}\end{array}$ \\
\hline DM, \% of feed & 88.2 & 89.2 & 36.6 & 48.9 & 85.6 & 73.7 & 86.2 & 82.9 & 88.8 \\
\hline $\mathrm{OM}, \%$ of $\mathrm{DM}$ & 87.2 & 88.1 & 96.2 & 86.5 & 95.7 & 98.7 & - & - & - \\
\hline NDF, $\%$ of DM & 27.5 & 38.0 & 40.3 & 42.9 & 48.4 & 8.4 & 5.2 & 64.0 & 3.6 \\
\hline $\mathrm{ADF}, \%$ of DM & 17.2 & 29.5 & 20.5 & 36.9 & 40.3 & 3.6 & - & - & - \\
\hline Lignin, \% of DM & 2.5 & 3.4 & 2.7 & 7.4 & 12.4 & 1.9 & - & - & - \\
\hline $\mathrm{CP}, \%$ of $\mathrm{DM}$ & 35.0 & 22.3 & 7.8 & 19.3 & 22.7 & 7.7 & 54.6 & 11.8 & 51.6 \\
\hline Soluble protein, $\%$ of $\mathrm{CP}$ & 25.2 & 21.0 & 53.2 & 67.0 & 22.6 & 40.4 & - & - & - \\
\hline ND-ICP, $\%$ of CP & 6.3 & 11.5 & 21.8 & 24.9 & 17.8 & 13.6 & - & - & - \\
\hline AD-ICP, $\%$ of CP & 3.7 & 5.4 & 6.4 & 6.3 & 7.3 & 3.1 & - & - & - \\
\hline
\end{tabular}

${ }^{1} \mathrm{ND}-\mathrm{ICP}=$ neutral detergent insoluble $\mathrm{CP} ; \mathrm{AD}-\mathrm{ICP}=$ acid detergent insoluble $\mathrm{CP}$.

${ }^{2} \mathrm{HMC}=$ High moisture corn grain; $\mathrm{SBM}=$ soybean meal; $\mathrm{SH}=$ soyhulls.

${ }^{3}$ Protected $\mathrm{SBM}=$ HiVap, Land O' Lakes/Purina Feed, Statesville, NC. 
Table 4. Crude protein degradation results from in situ analyses

\begin{tabular}{lcccc}
\hline Item & $\mathrm{A},{ }^{1} \%$ & $\mathrm{~B}, \%$ & $\mathrm{k}, \mathrm{h}^{-1}$ & $P_{\text {Model }}$ \\
\hline Corn silage & $77 \pm 0.57$ & 23 & $0.02 \pm 0.003$ & $<0.0001$ \\
Mix grass + legume silage & $76 \pm 1.19$ & 24 & $0.05 \pm 0.01$ & $<0.0001$ \\
Rolled high-moisture corn & $41 \pm 0.93$ & 59 & $0.05 \pm 0.003$ & $<0.0001$ \\
Soybean hulls & $32 \pm 2.95$ & 68 & $0.06 \pm 0.01$ & $<0.0001$ \\
Soybean meal, solvent-extracted $_{\text {Protected soybean meal }^{2}}$ & $31 \pm 2.22$ & 69 & $0.06 \pm 0.01$ & $<0.0001$ \\
Concentrate mix A $_{\text {Concentrate mix D }}^{15 \pm 1.83}$ & 85 & $0.02 \pm 0.002$ & $<0.0001$ \\
\hline
\end{tabular}

${ }^{1} \mathrm{~A}=$ soluble, $\mathrm{B}=$ insoluble $(100-\mathrm{A}), \mathrm{k}=$ degradation rate.
${ }^{2}$ Protected $\mathrm{SBM}=$ HiVap, Land O' Lakes/Purina Feed, Statesville, NC.

Gressley and Armentano (2007) also did not observe a loss in milk production when cows were fed a $7.4 \%$ RDP diet even though the diet was predicted to be $28 \%$ below predicted RDP requirements. Also, Reynal and Broderick (2005) demonstrated that decreasing dietary RDP from 12.5 to $7.7 \%$ did not result in a significant loss in milk yield. When Kalscheur et al. (2006) fed decreasing concentrations of RDP, they observed a trend for a linear decline in milk production. The diets in their study were formulated according to the previous NRC (1989) to contain a constant percentage of RUP and increasing percentage of RDP. However, according to the newer NRC (2001), predictions of RUP concentrations in their study decreased from 6.1 to $5.5 \%$ as RDP decreased from 11.0 to $6.8 \%$. It was, therefore, not clear

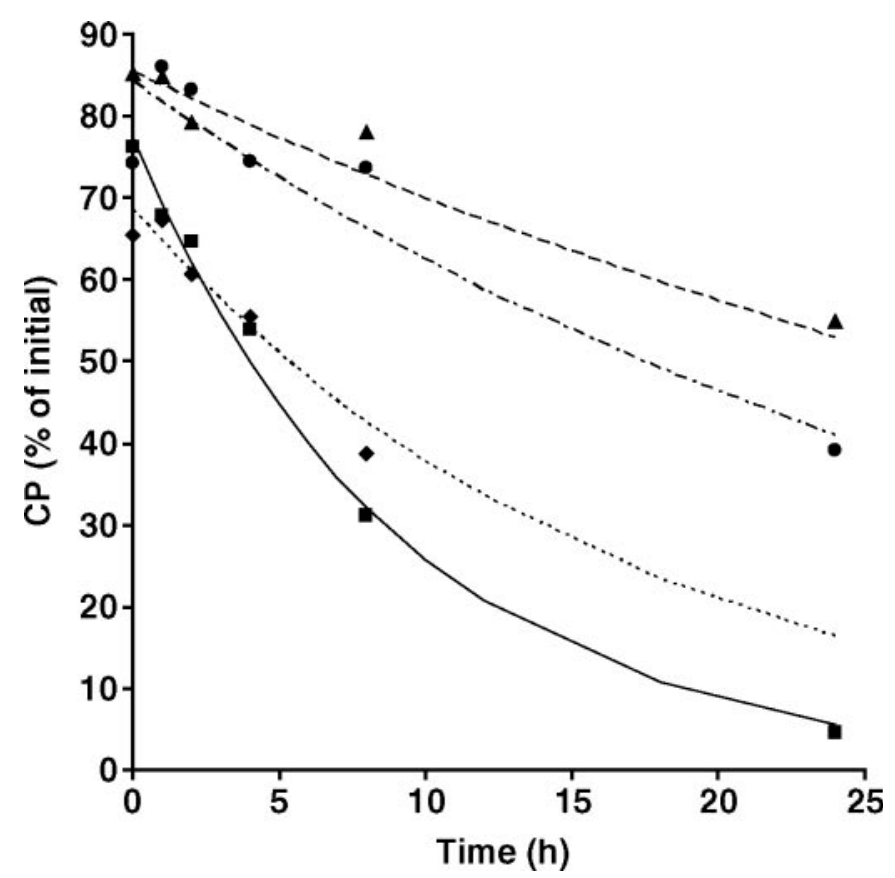

Figure 1. In situ crude protein degradability of predicted and observed concentrate mix A $(-, \mathbf{\square})$, concentrate mix D $(-\cdot-, \bullet)$, soybean meal $(\ldots, \bullet)$, and protected soybean meal $(--, \mathbf{\Delta})$ in the rumen. whether decreased RUP or RDP caused the trend for a linear decline in milk production in that study.

It is possible that the period length in our study was too short to allow full dietary responses. This seems unlikely if the low RDP diets compromised fiber digestion and energy supply because responses to energy restriction are very rapid (Carlson et al., 2006). Responses to a protein deficiency can take longer to manifest due to the buffering effect of labile protein reserves. However, Krober et al. (2000) observed maximal responses in MUN and milk yield by wk 3 when diets varying in $\mathrm{CP}$ content were fed to lactating cows for a period of 5 wk indicating that the 3 -wk periods used herein were adequate to test any potential MP deficiencies.

In spite of the linear decline in CP intake (Table 5), neither milk CP concentration nor milk protein yield were significantly affected by any of the treatment diets. Armentano et al. (1993) and Gressley and Armentano (2007) also observed no significant changes in milk protein content or yield with changes in RDP content of diets. But Reynal and Broderick (2005) observed positive linear effects for milk true protein content and a quadratic effect for true protein yield in association with dietary RDP concentrations ranging up to $12.5 \%$ (predicted from NRC, 2001; in vivo measurement was reported as $13.2 \%$ ) with maximum protein production at 10.9\% RDP (predicted from NRC, 2001; in vivo measurement was $12.3 \% \mathrm{RDP}$ ). Although current NRC (2001) recommendations for RDP range between 9.5 and $10.5 \%$ depending on the feeding program and animal characteristics, the NRC (2001) model predicts a quadratic relationship with maximum milk protein yields occurring at $12.2 \%$ RDP. However, production responses in the upper range occurred at the expense of a significant increase in estimated urinary $\mathrm{N}$ excretion (from 237 to $293 \mathrm{~g} / \mathrm{d}$ ) and a significant decrease in estimated environmental $\mathrm{N}$ efficiency (from 94.3 to 87.2 $\mathrm{kg}$ of milk per $\mathrm{kg}$ of $\mathrm{N}$ excreted). Reynal and Broderick (2005) concluded that if optimum N efficiency were the best compromise between the need for profitability and the need for preservation of the environment, the 
Table 5. Least squares means for intake, milk yield, milk composition, and body weight of dairy cows fed the experimental diets

\begin{tabular}{|c|c|c|c|c|c|c|c|c|}
\hline Item & \multicolumn{4}{|c|}{$\mathrm{RDP}, \%$ of diet $\mathrm{DM}$} & SEM & \multicolumn{3}{|c|}{ Contrast $(P<)^{1}$} \\
\hline \multicolumn{9}{|l|}{ Intake, kg/d } \\
\hline $\mathrm{CP}$ & 4.44 & 4.02 & 3.52 & 2.79 & 0.09 & $<0.0001$ & 0.10 & 0.70 \\
\hline $\mathrm{NDF}$ & 7.58 & 7.83 & 7.89 & 7.22 & 0.19 & 0.24 & 0.02 & 0.52 \\
\hline $\mathrm{ADF}$ & 4.49 & 4.79 & 4.97 & 4.66 & 0.12 & 0.21 & 0.02 & 0.49 \\
\hline Milk lactose, $\%$ & 4.87 & 4.88 & 4.86 & 4.88 & 0.03 & 0.92 & 0.96 & 0.61 \\
\hline Milk CP, \% & 2.98 & 3.00 & 3.01 & 2.92 & 0.05 & 0.45 & 0.25 & 0.66 \\
\hline Milk fat, $\%$ & 3.43 & 3.13 & 3.22 & 3.33 & 0.20 & 0.82 & 0.32 & 0.71 \\
\hline Milk lactose, $\mathrm{kg} / \mathrm{d}$ & 2.03 & 2.08 & 1.95 & 1.73 & 0.11 & 0.06 & 0.26 & 0.86 \\
\hline Milk CP, $\mathrm{kg} / \mathrm{d}$ & 1.23 & 1.26 & 1.21 & 1.07 & 0.06 & 0.11 & 0.20 & 0.60 \\
\hline Milk fat, kg/d & 1.43 & 1.33 & 1.28 & 1.15 & 0.08 & 0.02 & 0.91 & 0.71 \\
\hline MUN, mg/dL & 20.2 & 17.6 & 14.2 & 12.4 & 0.62 & $<0.0001$ & 0.58 & 0.40 \\
\hline
\end{tabular}

${ }^{\mathrm{a}, \mathrm{b}}$ Means in a row without common superscript letters differ at $P<0.01$. Pair-wise least squares mean comparison (Tukey) was conducted only for DMI.

${ }^{1}$ Contrasts: $\mathrm{L}=$ linear, $\mathrm{Q}=$ quadratic, $\mathrm{C}=$ cubic.

recommended level of RDP (in vivo) from their study would be $11.7 \%$ of DM $(9.2 \%$ dietary RDP using the NRC model).

Consistent with the lack of significant dietary effects on milk protein output, no differences in relative proportions of plasma essential AA concentrations were observed (Table 6). The only significant effect was a pair-wise difference for the nonessential amino acid serine for 10.1 and $8.8 \%$ RDP diets. Thus, neither the reduced DMI nor reduced supply of dietary RDP significantly altered plasma AA concentrations or milk protein. In their study, Foldager et al. (1980) reported that when lactating dairy cows were fed an MP-deficient diet (9.3\% protein) plasma branched-chain amino acids were decreased and glycine was increased presumably reflecting a shift between dietary sources and tissue mobilization. Because such a shift was not observed herein, it seems unlikely that significant tissue mobilization was occurring.

The apparent efficiency of $\mathrm{N}$ use for milk production was $27.7 \%$ for cows fed the high RDP diet (Table 7 ). Apparent nitrogen efficiency increased linearly $(P<$ $0.0001)$ with decreasing concentrations of RDP in the diet, the lowest RDP diet being most efficient (38.6\%) in converting feed protein into milk protein (Table 7 ). Increased $\mathrm{N}$ efficiency has important positive environmental implications with respect to air and water quality (Tamminga, 1992).

Milk urea nitrogen decreased linearly $(P<0.0001)$ from 20.2 to $12.4 \mathrm{mg} / \mathrm{dL}$ as dietary RDP declined across treatment diets (Table 5). The target range for MUN of Holstein cows is currently 8 to $12 \mathrm{mg} /$
dL (Kohn et al., 2002). However, the results reported herein suggest that an MUN concentration of $12 \mathrm{mg} /$ dL may be inadequate to support maximum production under some conditions because cows on the $8.8 \%$ RDP diet had a mean concentration of $14 \mathrm{mg} / \mathrm{dL}$. The observed values of MUN were higher than expected based on previous work. Results from a split-test (data not shown) ruled out analytical bias at the Virginia DHIA laboratory as a source of the unexpected results. Clearly genetics plays a role in MUN concentrations (Johnson and Young, 2003), which may explain the greater than expected values. Despite this difference, MUN concentrations were clearly responsive to dietary RDP (Table 5) and thus are useful for assessing overall $\mathrm{N}$ status of the animal.

Milk urea nitrogen can be used as a rapid and noninvasive way to estimate urinary $\mathrm{N}$ excretion from dairy cows. According to Wattiaux and Karg (2004), urinary $\mathrm{N}$ excretion $(\mathrm{g} / \mathrm{d})$ can be predicted as $0.0283 \times \mathrm{BW}$ $(\mathrm{kg}) \times$ MUN $(\mathrm{mg} / \mathrm{dL})$. Predicted daily excretion of urinary $\mathrm{N}$ was significantly higher for animals fed the high RDP diets $(P<0.0001)$. Evidence from other studies of urinary $\mathrm{N}$ excretion support linear decreases in urinary $\mathrm{N}$ excretion with decreasing dietary CP (Davidson et al., 2003; Reynal and Broderick, 2005; Kalscheur et al., 2006). Calculating $\mathrm{N}$ excretion in feces assuming no changes in body $\mathrm{N}$ mobilization results in a linear reduction in fecal $\mathrm{N}$ output $(P<0.0001)$ from 178 to $75 \mathrm{~g} / \mathrm{d}$ as dietary RDP decreased from 11.3 to $7.6 \%$ of DM. Such large changes in predicted fecal N output (g/d) are not consistent with the observations of Hristov et al. (2004) and Gressley and Armentano (2007) 
Table 6. Relative proportions of free AA (as \% of total AA) in plasma of cows fed the experimental diets

\begin{tabular}{|c|c|c|c|c|c|c|}
\hline \multirow{2}{*}{$\begin{array}{l}\text { Amino acid, } \\
\% \text { of total AA }\end{array}$} & \multicolumn{4}{|c|}{$\mathrm{RDP}, \%$ of diet $\mathrm{DM}$} & \multirow[b]{2}{*}{ SEM } & \multirow[b]{2}{*}{$P$-value } \\
\hline & 11.3 & 10.1 & 8.8 & 7.6 & & \\
\hline \multicolumn{7}{|l|}{ Essential AA } \\
\hline His & 2.5 & 2.2 & 2.2 & 2.4 & 0.001 & NS \\
\hline Ile & 6.6 & 6.5 & 6.3 & 6.5 & 0.003 & NS \\
\hline Leu & 7.3 & 7.3 & 7.0 & 7.5 & 0.004 & NS \\
\hline Lys & 4.6 & 4.3 & 4.3 & 4.2 & 0.002 & NS \\
\hline Met & 0.8 & 0.7 & 0.8 & 0.7 & 0.005 & NS \\
\hline Phe & 1.6 & 1.6 & 1.6 & 1.9 & 0.001 & NS \\
\hline Thr & 5.2 & 5.2 & 4.0 & 4.5 & 0.003 & NS \\
\hline Trp & 1.7 & 1.6 & 1.6 & 1.6 & 0.001 & NS \\
\hline Val & 14.9 & 14.8 & 13.5 & 14.0 & 0.007 & NS \\
\hline \multicolumn{7}{|c|}{ Nonessential AA } \\
\hline Ala & 12.5 & 12.7 & 12.7 & 14.2 & 0.7 & NS \\
\hline Asp & 0.4 & 0.3 & 0.4 & 0.3 & 0.03 & NS \\
\hline Gln & 11.1 & 10.8 & 10.4 & 9.9 & 0.006 & NS \\
\hline Glu & 2.6 & 2.6 & 2.6 & 2.4 & 0.002 & NS \\
\hline Gly & 17.5 & 19.7 & 21.5 & 19.5 & 0.02 & NS \\
\hline Pro & 4.3 & 4.4 & 4.3 & 4.4 & 0.002 & NS \\
\hline Ser & $4.1^{\mathrm{ab}}$ & $3.5^{\mathrm{a}}$ & $4.4^{\mathrm{b}}$ & $4.5^{\mathrm{b}}$ & 0.002 & 0.05 \\
\hline Tyr & 1.9 & 1.8 & 1.8 & 1.9 & 0.001 & NS \\
\hline
\end{tabular}

${ }^{\mathrm{a}, \mathrm{b}}$ Means in a row without common superscripts differ at $P<0.05$.

who observed no relationship between fecal $\mathrm{N}$ output (g/d) and dietary RDP. However, when our results are expressed as a percentage of $\mathrm{N}$ intake, the 3 diets with the greatest RDP had relatively constant proportions of intake $\mathrm{N}$ not accounted for in milk $\mathrm{N}$ and predicted urinary output with values of 25,21 , and $24 \%$, respectively. The lowest $\mathrm{CP}$ diet had a predicted fecal output plus retained $\mathrm{N}$ of $17 \%$. The latter value could be an indication that mobilization did occur, although increased digestion efficiency cannot be ruled out given the significant reduction in DMI. Both Gressley and Armentano (2007) and Hristov et al. (2004) reported that as proportion of intake, fecal $\mathrm{N}$ losses were significantly greater for low RDP diets compared with high RDP diets. A possible explanation for our results is the apparent slight reduction in RUP as dietary RDP was decreased (Table 8). This resulted from slightly lower
CP concentrations in concentrate $\mathrm{D}$ as compared with the formulated diet (Table 2).

Milk fat percentage was not affected by diet, but milk fat yield decreased linearly $(P=0.02)$ from 1.43 to 1.15 $\mathrm{kg} / \mathrm{d}$ as RDP in the diet decreased from 11.3 to $7.6 \%$ of DM (Table 5). Gressley and Armentano (2007) noticed no significant changes in milk fat content and yield in a similar study with 7.4 and $10.1 \%$ RDP in diets. Also, Armentano et al. (1993) reported no changes in milk fat content or yield with changes in RDP in diets. Methionine and lysine may play a role in milk fat synthesis through increased de novo synthesis of short- and medium-chain fatty acids or through increased synthesis of chylomicra and very low density lipoproteins (NRC, 2001). However, no significant changes in plasma methionine or lysine concentrations were observed (Table 6), suggesting that another mechanism was responsible.

Table 7. Nitrogen efficiency of cows fed the experimental diets

\begin{tabular}{|c|c|c|c|c|c|c|c|c|}
\hline Item & \multicolumn{4}{|c|}{$\mathrm{RDP}, \%$ of diet $\mathrm{DM}$} & SEM & \multicolumn{3}{|c|}{ Contrast $^{1}$} \\
\hline Intake $\mathrm{N}, \mathrm{g} / \mathrm{d}$ & 719 & 613 & 544 & 453 & 14.6 & $<0.0001$ & 0.62 & 0.36 \\
\hline Predicted urine $\mathrm{N}^{2} \mathrm{~g} / \mathrm{d}$ & 350 & 304 & 248 & 210 & 11.3 & $<0.0001$ & 0.74 & 0.62 \\
\hline Predicted fecal N, ${ }^{3} \mathrm{~g} / \mathrm{d}$ & 178 & 128 & 133 & 75 & 13.4 & $<0.0001$ & 0.78 & 0.07 \\
\hline $\mathrm{N}$ efficiency, ${ }^{4} \%$ & 27.7 & 30.9 & 35.5 & 38.6 & 1.2 & $<0.0001$ & 0.99 & 0.60 \\
\hline
\end{tabular}

${ }^{1}$ Contrasts: $\mathrm{L}=$ linear, $\mathrm{Q}=$ quadratic, $\mathrm{C}=$ cubic.

${ }^{2}$ Predicted urine $\mathrm{N}$ output $=0.0283 \times \mathrm{MUN}(\mathrm{mg} / \mathrm{dL}) \times \mathrm{BW}(\mathrm{kg})$. (Wattiaux and Karg, 2004).

${ }^{3}$ Predicted fecal $\mathrm{N}=\mathrm{N}$ intake - predicted urinary $\mathrm{N}-$ milk $\mathrm{N}$.

${ }^{4} \mathrm{~N}$ efficiency $(\%)=100 \times$ Milk N (g/d) / Intake N (g/d). 
Table 8. Predicted protein requirements and allowable milk production using the NRC (2001) model and observed diet composition and DMI

\begin{tabular}{lcccc}
\hline & \multicolumn{4}{c}{ RDP, \% of diet DM } \\
\cline { 2 - 5 } NRC prediction $^{1}$ & 11.3 & 10.1 & 8.8 & 7.6 \\
\hline CP, \% of DM & 18.3 & 16.9 & 15.4 & 14.0 \\
RDP, \% of DM & 11.2 & 10.0 & 8.7 & 7.6 \\
RUP, \% of DM & 7.1 & 6.9 & 6.7 & 6.4 \\
NE, Mcal/kg & 1.61 & 1.61 & 1.61 & 1.65 \\
RDP required, g/d & 2,388 & 2,379 & 2,331 & 2,097 \\
RDP supplied, g/d & 2,707 & 2,380 & 2,022 & 1,545 \\
RDP balance, g/d & 319 & 1 & -308 & -552 \\
RUP required, g/d & 1,463 & 1,531 & 1,682 & 1,676 \\
RUP supplied, g/d & 1,708 & 1,649 & 1,551 & 1,299 \\
RUP balance, g/d & 245 & 118 & -131 & -376 \\
MP balance, g/d & 211 & 101 & -112 & -320 \\
NE allowable milk, kg/d & 42 & 43.2 & 41.3 & 35.4 \\
MP allowable milk, kg/d & 46 & 44.4 & 37.8 & 29.3 \\
\hline
\end{tabular}

${ }^{1}$ Values predicted using actual DMI, ingredient composition, milk yield, and milk composition for each treatment (NRC, 2001).

Table 8 reports NRC (2001) predicted protein supplies and requirements using observed treatment means for DMI, ingredient composition, milk production, and milk composition. As noted previously, these predictions indicated that RUP did not remain constant as originally formulated but declined from 7.1 to $6.4 \%$ of diet $\mathrm{DM}$ as RDP\% decreased from 11.3 to $7.6 \%$ in diets. But this predicted decline should not have resulted in an MP deficiency for the 3 diets with the greatest $\mathrm{CP}$ content because the loss in RUP was roughly $100 \mathrm{~g} / \mathrm{d}$ for each step down in $\mathrm{CP}$ with the base diet being over $200 \mathrm{~g} / \mathrm{d}$ in excess of requirements. Cows on high RDP diets (11.3 and $10.1 \%$ ) produced less milk than MP allowable milk production according to NRC (2001) predictions indicating that those diets were adequate in RDP. Conversely, milk yields were higher than predicted for the 8.8 and $7.6 \%$ RDP diets, indicating the model overestimated requirements for these cows. For the $8.8 \%$ RDP diet the predicted RDP supply was only $87 \%$ of that required with a RDP balance of $-308 \mathrm{~g} / \mathrm{d}$. As dietary RDP declined, the NRC (2001) model predicted greater RUP requirements to meet predicted MP requirements given the predicted decline in microbial yields. As additional dietary RUP was not provided, negative RUP and MP balances were predicted. It is not clear whether the reduced RDP or RUP caused the trend for reduced milk yield associated with the lowest RDP diet because RUP decreased along with $\mathrm{RDP}$ in this diet. However, cows on the $7.6 \%$ RDP diet produced $25 \%$ more milk than NRC (2001) predicted from MP allowable milk.

\section{CONCLUSIONS}

Mid-lactation dairy cows fed RDP diets as low as $8.8 \%(15.9 \% \mathrm{CP})$ of DM maintained DMI, milk yields, and milk protein yields compared with cows fed high RDP diets during this study. This observation suggests that ruminal microbial RDP requirements may be met with levels of RDP below those recommended in the current NRC (2001). Feeding less RDP and CP improved apparent $\mathrm{N}$ efficiencies from 27.7 to $33.5 \%$ without a significant loss in productivity. A further improvement in efficiency to $38.6 \%$ was achieved with a trend for lost milk production. Such improvements in $\mathrm{N}$ efficiency will have positive environmental impacts.

\section{ACKNOWLEDGMENTS}

This material is based upon work supported by the Cooperative State Research, Education and Extension Service, USDA, under project no. NC-1009. Departmental funding provided by the Virginia State Dairymen's Association is gratefully acknowledged. The authors thank Shane Brannock and the dairy farm crew at Virginia Tech for help with animal care. We appreciate the help of Chris Umberger, Greta Moyer, and Ashley Elgin with sample collection and analysis. Any opinions, findings, conclusions, or recommendations expressed in this publication are those of the author(s) and do not necessarily reflect the view of the USDA.

\section{REFERENCES}

Allen, M. S. 2000. Effects of diet on short-term regulation of feed intake by lactating dairy cattle. J. Dairy Sci. 83:1598-1624.

AOAC. 1997. Official Methods of Analysis. AOAC Int., Gaithersburg, MD.

Armentano, L. E., S. J. Bertics, and J. Riesterer. 1993. Lack of response to addition of degradable protein to a low protein diet fed to midlactation dairy cows. J. Dairy Sci. 76:3755-3762.

Bequette, B. J., M. D. Hanigan, and H. Lapierre. 2003. Mammary uptake and metabolism of amino acids by lactating ruminants. Page 347 in Amino Acids in Farm Animal Nutrition. J. P. F. D'Mello, ed. CABI Publishing, Wallingford, UK. 
Carlson, D. B., N. B. Litherland, H. M. Dann, J. C. Woodworth, and J. K. Drackley. 2006. Metabolic effects of abomasal L-carnitine infusion and feed restriction in lactating Holstein cows. J. Dairy Sci. 89:4819-4834.

Christensen, R. A., M. R. Cameron, J. H. Clark, J. K. Drackley, J. M. Lynch, and D. M. Barbano. 1994. Effects of amount of protein and ruminally protected amino acids in the diet of dairy cows fed supplemental fat. J. Dairy Sci. 77:1618-1629.

Christensen, R. A., G. L. Lynch, J. H. Clark, and Y. Yu. 1993 Influence of amount and degradability of protein on production of milk and milk components by lactating holstein cows. J. Dairy Sci. $76: 3490-3496$.

Clark, J. H., T. H. Klusmeyer, and M. R. Cameron. 1992. Microbial protein synthesis and flows of nitrogen fractions to the duodenum of dairy cows. J. Dairy Sci. 75:2304-2323.

Davidson, S., B. A. Hopkins, D. E. Diaz, S. M. Bolt, C. Brownie V. Fellner, and L. W. Whitlow. 2003. Effects of amounts and degradability of dietary protein on lactation, nitrogen utilization, and excretion in early lactation Holstein cows. J. Dairy Sci. $86: 1681-1689$.

El-Kadi, S. W., R. L. Baldwin, N. E. Sunny, S. L. Owens, and B. J. Bequette. 2006. Intestinal protein supply alters amino acid, but not glucose, metabolism by the sheep gastrointestinal tract. J. Nutr. 136:1261-1269.

Firkins, J. L., L. L. Berger, N. R. Merchen, G. C. Fahey Jr, and D. R. Nelson. 1986. Effects of feed intake and protein degradability on ruminal characteristics and site of digestion in steers. J. Dairy Sci. 69:2111-2123.

Foldager, J., J. T. Huber, and W. G. Bergen. 1980. Factors affecting amino acids in blood of dairy cows. J. Dairy Sci. 63:396-404.

Gressley, T. F., and L. E. Armentano. 2007. Effects of low rumendegradable protein or abomasal fructan infusion on diet digestibility and urinary nitrogen excretion in lactating dairy cows. J. Dairy Sci. 90:1340-1353.

Hristov, A. N., R. P. Etter, J. K. Ropp, and K. L. Grandeen. 2004 Effect of dietary crude protein level and degradability on ruminal fermentation and nitrogen utilization in lactating dairy cows. J. Anim. Sci. 82:3219-3229.

James, T., D. Meyer, E. Esparza, E. J. Depeters, and H. PerezMonti. 1999. Effects of dietary nitrogen manipulation on ammonia volatilization from manure from Holstein heifers. J. Dairy Sci. $82: 2430-2439$

Johnson, R. G., and A. J. Young. 2003. The association between milk urea nitrogen and DHI production variables in western commercial dairy herds. J. Dairy Sci. 86:3008-3015.

Kalscheur, K. F., R. L. Baldwin, B. P. Glenn, and R. A. Kohn. 2006. Milk production of dairy cows fed differing concentrations of rumen-degraded protein. J. Dairy Sci. 89:249-259.

Kohn, R. A., K. F. Kalscheur, and E. Russek-Cohen. 2002. Evaluation of models to estimate urinary nitrogen and expected milk urea nitrogen. J. Dairy Sci. 85:227-233.

Krober, T. F., D. R. Kulling, H. Menzi, F. Sutter, and M. Kreuzer. 2000. Quantitative effects of feed protein reduction and methionine on nitrogen use by cows and nitrogen emission from slurry. J. Dairy Sci. 83:2941-2951.

Licitra, G., T. M. Hernandez, and P. J. Van Soest. 1996. Standardization of procedures for nitrogen fractionation of ruminant feeds. Anim. Feed Sci. Technol. 57:347-358.

National Research Council. 1989. Nutrient Requirements of Dairy Cattle. 6th rev. ed. Natl. Acad. Sci., Washington, DC.

National Research Council. 2001. Nutrient Requirements of Dairy Cattle. 7th rev. ed. Natl. Acad. Sci., Washington, DC.

Reynal, S. M., and G. A. Broderick. 2005. Effect of dietary level of rumen-degraded protein on production and nitrogen metabolism in lactating dairy cows. J. Dairy Sci. 88:4045-4064.

Santos, F. A., J. E. Santos, C. B. Theurer, and J. T. Huber. 1998. Effects of rumen-undegradable protein on dairy cow performance: A 12-year literature review. J. Dairy Sci. 81:3182-3213.

Tamminga, S. 1992. Nutrition management of dairy-cows as a contribution to pollution-control. J. Dairy Sci. 75:345-357.

Van Soest, P. J., J. B. Robertson, and B. A. Lewis. 1991. Methods for dietary fiber, neutral detergent fiber, and nonstarch polysaccharides in relation to animal nutrition. J. Dairy Sci. 74:3583-3597.

Varel, V. H., J. A. Nienaber, and H. C. Freetly. 1999. Conservation of nitrogen in cattle feedlot waste with urease inhibitors. J. Anim. Sci. 77:1162-1168.

Wattiaux, M. A., and K. L. Karg. 2004. Protein level for alfalfa and corn silage-based diets: II. Nitrogen balance and manure characteristics. J. Dairy Sci. 87:3492-3502. 